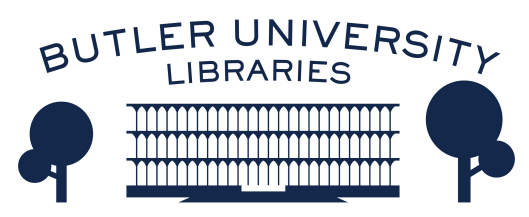

Journal of Hindu-Christian Studies

Volume 26

Article 6

November 2013

\title{
Author's Response: Cognitive Science, History-Centrism and the Future of Hindu Studies
}

Rajiv Malhotra

Infinity Foundation

Follow this and additional works at: https://digitalcommons.butler.edu/jhcs

Part of the Religion Commons

\section{Recommended Citation}

Malhotra, Rajiv (2013) "Author's Response: Cognitive Science, History-Centrism and the Future of Hindu Studies," Journal of Hindu-Christian Studies: Vol. 26, Article 6.

Available at: https://doi.org/10.7825/2164-6279.1545

The Journal of Hindu-Christian Studies is a publication of the Society for Hindu-Christian Studies. The digital version is made available by Digital Commons @ Butler University. For questions about the Journal or the Society, please contact cbauman@butler.edu. For more information about Digital Commons @ Butler University, please contact digitalscholarship@butler.edu. 
Malhotra: Author's Response

\section{Author's Response: Cognitive Science, History- Centrism and the Future of Hindu Studies Rajiv Malhotra Infinity Foundation}

I thank all three responders to my books for their careful and detailed consideration of my work. I will address the following concerns that they raise:

- their challenge to my claim that the dharmic traditions are more in tune with modern cognitive science than the Abrahamic ones are

- their challenge to my claim that historycentrism in the Abrahamic faiths is an important point of difference

- their claim that I ignore how historical forces influence dharma

- their claim against a coherent Hindu philosophy and unity

- Brian Pennington's tension with the reality that the academy seeks to engage me.

\section{Response to Rambachan}

Anantanand Rambachan has given the most thorough and substantive response to my work, and I thank him for it. We disagree primarily on two points: the question of the relationship of science to adhyatma vidya, or the inner meditative practices taught by dharmic traditions, and the issue of the coherence and integral unity of Hinduism. Rambachan regards the association of Hinduism with science as spurious and misleading, a product of the distorting influence of the West on such Hindu figures as Vivekananda and Aurobindo. He also regards any claim to a Hindu unity as largely a construct of colonialism. In both cases, he thinks my views discount the role of the exegetical tradition of Vedanta as insisted upon by Shankara vis-à-vis direct inner experience. In fact, I have asserted that the modern Hindu thinkers have revitalized and expanded their tradition in a way that is entirely in line with the past, that dharma has never been in tension with science, and that in fact dharma and today's cognitive science come close to converging. I also hold that Hindu dharma has

Rajiv Malhotra is an Indian-American researcher and public intellectual interested in the philosophy of science, religion, and civilizations. A scientist by training, he is full-time founder-director of Infinity Foundation (Princeton, NJ), serves as Chairman of the Board of Governors of the Center for Indic Studies (University of Massachusetts, Dartmouth), and is adviser to various organizations. In addition to BEING DIFFERENT: An Indian Challenge to Western Universalism (Harpercollins, 2011), he has coauthored with Aravindan Neelakandan Breaking India: Western Interventions in Dravidian and Dalit Faultlines, (Amaryllis, 2011). His INDRA'S NET: Reclaiming Swami Vivekananda's Vision will appear with Harpercollins in 2014. He is finishing up a two-volume work on Buddhist Influences on the Mind Sciences, under contract with Harpercollins. 
a valuable and coherent past, present and future with highly developed adhyatmic practices and experiences.

I agree with Rambachan's desire to protect Advaita Vedanta's non-dualism and I share his position on the utter unknowability of the divine by means of ordinary consciousness, owing to the subject/object split. I also share his interest in preserving the diversity of the Hindu dharma vis-à-vis those who would reduce it to homogeneity. However, I part company when he argues for reliance solely on third-person textual authority for knowing Brahman. As I shall explain, he is working from some wrong assumptions about the nature of science, the Vedanta-yoga relationship, and the internal coherence and innate pluralism of the dharma traditions.

It should be noted that Rambachan and I come from different intellectual backgrounds and therefore adopt different approaches to the matter at hand. I speak from a background in science as well as personal sadhana in several dharmic approaches, based on which I have extensively researched the Western appropriation of Indian thought in psychology, cognitive sciences, cosmology, philosophy and religion. Rambachan takes what I believe to be a more bookish and narrow approach that is exclusively focused on Advaita Vedanta and steeped in hermeneutical and exegetical problems that arise from the use of the JudeoChristian paradigm for religious studies. My most important conversations and debates have been in the philosophy of science and the history of the transmission of ideas from India to the West. His have been largely in academic religious studies.

The result is an ironic "disconnect." Not only is Rambachan unaware of how closely contemporary scientific thought accords with a wide range of dharmic views and practices; he fails to see that this area of thought itself draws directly and extensively on Indian sources. A large part of my work has to do with tracking and repositioning certain Indian sources that are at the heart of the confluence of science and spirituality, which is the cutting edge of Western thought. By contrast, Rambachan refutes the validity of these ideas in Hindu dharma. So the West appropriates what Rambachan considers inauthentic. This disconnect gets my attention.

Furthermore, his assertion that Hinduism lacks coherence is mistaken, as well as debilitating insofar as it deprives Hinduism of its potential for providing an open architecture of faiths that could serve as the basis for a truly pluralist framework for humanity. Rambachan's sweeping rejection of modern Hinduism (which he pejoratively calls "neoHinduism") cuts this project off at the knees. His emphasis on the primacy of the exegetical tradition of Advaita Vedanta, while in many ways a valuable corrective to the "anything goes" kind of Hindu thinking that tends to prevail, is both extreme and limiting.

Rambachan could make a great contribution to Hindu Studies if he could only recognize the new paradigms emerging in science and religion and accept a broader definition of what Hinduism is and how it relates to contemporary Western thought. Were he to open his eyes to the Western appropriation of Hindu ideas, he might (given his expertise) be able to shed some muchneeded light on the matter in terms of clarification and correction. 


\section{'New' paradigms imported from India into the West}

My book Being Different claims that the inner sciences of the dharmic traditions are closer to the spirit and substance of contemporary scientific inquiry than are the beliefs and practices of the Abrahamic religions. Rambachan's resistance to this claim is the basis of much of his critique of my work (and of modern Hinduism in general). In my view, his phobic response to the association of science and religion is based on an outdated paradigm of science. What's more, it reflects a narrow reading of the dharmic traditions. He underestimates, for example, the significance of direct inner inquiry and first-person experience in Shankara's teachings and in Hinduism and Buddhism in general.

Rambachan insists on denying the connection between dharmic meditative practices and the methods and metaphysical assumptions of cognitive science as they are practiced today. He ignores both the empirical nature of the rishis' experience and the new scientific paradigms that are emerging. I wish to stress that Hindus have had no cause to be afraid of science in the way the Abrahamic traditions have had cause, and that is because the metaphysical and theological assumptions of dharma are not dependent on the defense of dogmatic historical revelations. Furthermore, contemporary physics and cognitive science challenge precisely the dualistic model of subject/object split - and they challenge it in terms actually appropriated from the study of Hinduism and Buddhism. It is first-person experience and experiment that bind dharma and cognitive science together. Once this new paradigm of cognitive science became crystallized with the help of Hindu and
Buddhist sources, it became generalized into a broader discourse on "science and religion," one which permeates the academy today (except ironically in the study of Indian religions).

In simple terms, this scientific paradigm developed from the recognition of the role of the observer in cognition. Newtonian physics assumed an objective reality independent of consciousness. This is now considered reductionist. The recent scientific shift is toward a metaphysics that is closer to the cosmology of the Upanishads than to Christian theological constructs (based, as they usually are, on classical Greek models). This new insight involves cultivating the ability to experience reality in radically new ways. The new scientists of cognition know Hinduism to be closely related to their field, and adhyatma vidya is positioned as an important means of scientific inquiry. Rambachan's refusal to engage with my work is therefore indicative of a broader dis-connect between academic Hinduism studies and the emerging cognitive science.

Rambachan would probably agree with me that this interrelation between science and dharma should not be studied (as it often has been) by shearing off the cultural, religious and philosophical context in which it was born. This attempt to "sanitize" what is trivialized as "eastern wisdom" and repackage it in western secular scientific terms has been going on for too long. A large part of my current work is aimed at documenting and understanding this process of "digestion" and deracination.

The pattern is a recurring one: an intellectual entrepreneur "goes east" in much the same way that American frontiersmen "went west." He may feel that the Abrahamic 
religions are too restrictive or oppressive, and/or that they are intellectually bankrupt in the face of new evidence in physics, psychology and healing sciences. New treasures are unearthed during this process of eastern exploration, and these are especially prized when they can be made to operate outside of accepted western categories, including the category of religion itself. At first, the Indian aspects of these new bodies of knowledge are noted and relished as the basis on which the entrepreneur/frontiersman can establish himself as an expert before his western peers. But as that knowledge gets repackaged for consumption in the West, the original contexts are removed and left behind as "exotica."

The repackaged knowledge and new disciplines supersede the old Western religious paradigms. Removing the original Indian contexts leads to forms of perennial philosophy or secular scientism which are supposedly value-free and operate outside of religious myths and devotional practices. In my view, this is a mistake, and if Rambachan believes Vedanta is in need of being protected from this deracination and de-contextualization, then I entirely agree with him. But it would also be a great mistake to throw the baby out with the bathwater, i.e., to deny all relationships between dharmic traditions and the new science.

The chart below shows the "digestion" process by which dharma gets assimilated into modern cognitive science. It shows the Indian sources of the new scientific paradigm and lists some of the channels by which those sources have entered Western consciousness, as well as some ways in which they have constituted and shaped new areas of study (even new departments in the academy). These sources have, in effect, redrawn the boundaries of what is considered science today.

The box on the top left lists some of the main dharmic sources that have been mined, and that continue to be mined in this enterprise. These Indian source traditions include: Buddhism (especially Zen and IndoTibetan), Kashmir Shaivism, Patanjali's yoga, Tantra, Vedanta (especially Advaita and Vishitadvaita), Vipassana, and the work of Sri Aurobindo. This is far from an exhaustive list, and one could easily add other influences such as J. Krishnamurti, Ramana Maharshi, Vivekananda and Paramahansa Yogananda, to name just a few.

The box at the top right lists a few of the many Western organizations involved in this large-scale project. The Western disciplines digesting this knowledge encompass philosophy, psychology, neuroscience, religion, medicine, and so on. I have been studying several of these groups for a forthcoming series of books which will explore how Western organizations go about identifying, selecting, validating and repackaging the dharmic knowledge, and then claim the status of "original discoverers" by gradually erasing the source traditions. (In Being Different, I explain how lack of acknowledgment in this appropriation differs from the appropriations that were made from Hellenistic sources, and why Western scholars do not treat Indian and Hellenistic sources on par.)

The Western players cited in the top right box have criticized the old-school approach taken by Western religions, science, psychology and philosophy. They find these disciplines to be reductionist and in need of radical reform. They often criticize Western thought by turning directly and primarily to Indian 
sources, and they do so to a degree that is not sufficiently recognized. The two lower boxes indicate that this "churning" process in the West is crystalizing into well-defined and wellrespected fields that are rapidly becoming accepted into the mainstream academy. This appropriation from India and tension or conflict in the West between old and new models started a century ago, but the challenges to older paradigms have recently intensified, prompting a dramatic rethinking in mainstream circles. The very notions of science and religion are changing.

Indian gurus both in India and in the West trained individual American "frontiersmen," who then turned the knowledge gained at the feet of those teachers into what was at first a fringe movement. Over the past two generations, these proto-movements have solidified and advanced from the fringe to the mainstream of Western research, all the while losing sight of, or repressing, their Indian roots. The list of mainstream institutions and major intellectual figures participating in this process is indeed impressive. There has often been a double role played by the various intermediaries, individuals as well as institutions.

- These intermediaries appropriate from dharma what is (or until recently was) novel in the West, and often express harsh criticism of the prevailing Western religious models. This helps them get established as pioneers and original thinkers for Western audiences.

- Once the Indian sources have been used to gather knowledge and create credibility for themselves, the intermediaries dilute the significance of those sources (this often involves elaborate cover-ups) and sometimes even attack the dharmic sources as being inferior.

The framework for this "digestion," as I call it, is partly secular science and partly JudeoChristianity. While many appropriations have entered directly into Christianity (such as Christian Centering Prayer from T.M., Christian Yoga from Hindu Yoga, to name only two), others have arrived via a longer route. This latter category includes holistic healing, neurosciences, and cognitive sciences.

As I have said, much of my disagreement with Rambachan centers around (1) his lack of awareness of what science is today and (2) the absorption of Indian thought into this new science. My approach is different. When I use the term "adhyatma vidya," for instance, I'm relating it to the modes of empirical inquiry as currently understood in cognitive science. This method involves first-person experience combined with third-person analysis of mind. Rambachan works from a different model of what science is and he finds it to be antithetical to Advaita Vedanta. We also differ on the importance of text and transmission in dharmic traditions vis-à-vis the West, an issue to which I will return. 


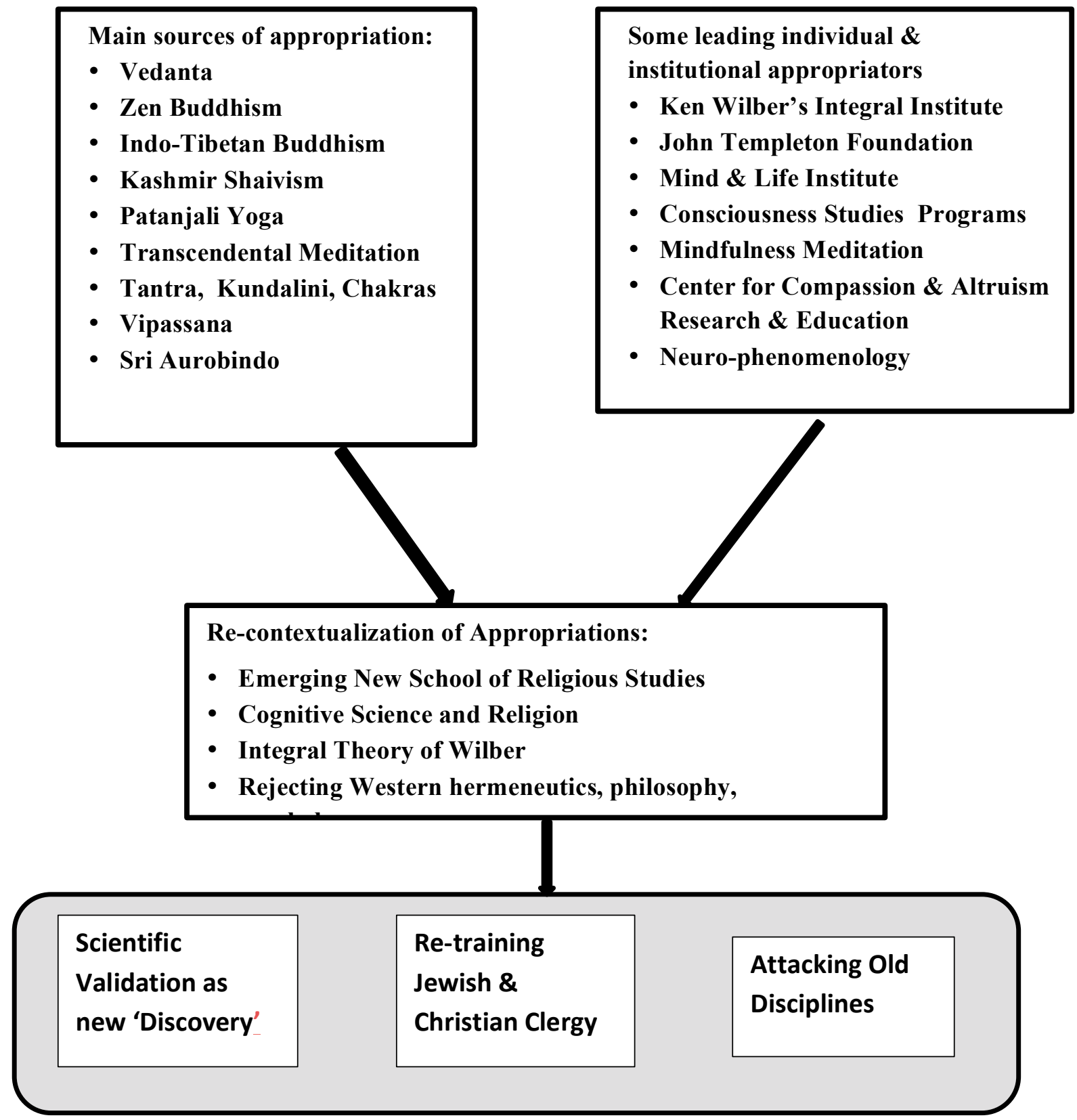

Figure 1

New Science of Consciousness without dualism/objectification

Rambachan cites Shankara as the great counter-example to my emphasis on adhyatma vidya. He makes the valid point that Shankara considers the Vedas to be the only way of knowing Brahman. Along with this, Rambachan argues that science deals only with dualistic objects, i.e., it objectifies whatever object is being studied as something that exists 
independently of the subject. It is true that this dualistic method cannot lead one to knowledge of Brahman, but Rambachan shows an awareness only of old-school science when he makes this point.

Quantum mechanics has radically changed science in this regard. According to QM (as per many interpretations), consciousness plays a role as the observer in "creating" (by collapsing into) the state of the object that is observed. In other words, there is no particular state that the object is in until it is observed. Prior to an object's being observed, what we have are probabilities for its existence in various possible states. In a sense, the very act of observation "creates" the state of the object in which it is found.

The link between this new physics and dharma has been noted since the discovery of QM by Heisenberg and Schrodinger (both Nobel Laureates in physics). Each of these pioneers cited the Upanishads as the only source of philosophy known to them that was consistent with the paradoxical nature of reality according to QM. ${ }^{1}$ Western philosophical frameworks at that time (the 1920s and early '30s) failed to accommodate any such possibility as QM. This ushered in a new era of speculative research into the nature of consciousness and its relationship with the physical cosmos.

Most of the early philosophical explanations of QM explicitly invoked ideas from Vedanta. There was a frenzied attempt to replace the separate Western frameworks for consciousness and matter with a unified framework based on Vedanta. (In most dharma, metaphysical systems, consciousness, and matter were never separate frameworks.) The research literature on such ideas in the West has mushroomed and now spans many fields, including the philosophy of science, psychology, arts, neuroscience, religion, healing, etc. I shall not attempt here to present a tutorial on this vast terrain. Suffice it to say that the term "first-person empiricism" is now widely accepted as the means to knowing consciousness directly by experiencing nondual states. Although initially marginalized upon its arrival in the West, this new paradigm has become respectable and is seriously challenging old reductionist views of science.

What is most relevant to our discussion is that the pioneers in this science of consciousness start off by attacking the classical Western (Newtonian and Cartesian) models as being reductionist, and precisely for the reasons cited by Rambachan: the models are dualistic in their separation of subject and object, and assume wrongly that objects have a separate self-existence. Rambachan, then, cannot very well accuse the new science of consciousness of the very problem it seeks to resolve, i.e., the reductionism intrinsic in "objectification" as practiced in scientific enquiry.

\section{Are we all potential rishis?}

I call adhyatma vidya "inner science" for a reason, which is to emphasize that after the rishis meditated and articulated in the Upanishads what they "saw," these first-person experiences were systematized and debated in peer reviews in India. This tradition of purva paksha and uttara paksha is how major Indian systems were established, i.e., through a combination of empirical observation, argumentation, and peer review which strongly resembles the scientific method. This process has never been in tension with the scientific 
method because it is not bound to absolutist claims of history that are non-reproducible and hence non-verifiable. It is this conjunction that Vivekananda and other modern Hinduism intuited and that is being developed today.

Rambachan has not addressed the key question: How did the rishis "see" the shruti in the first place? Unlike the Abrahamic religions, in which prophets hear from an external God, in the Vedas there is no external voice. There is no entity equivalent to Yahweh who speaks the Vedas to the rishis. Nobody says anything like: "I am Brahma, the Creator, and I am giving you these covenants . . ." So Rambachan must explain how the Vedas were "seen" by the rishis.

He cannot respond by saying that the Vedas were original compositions by the rishis, because Vedas are a-purusheya, i.e., beginningless and authorless. They existed before the rishis "saw" them. So if the rishis neither composed them nor heard them spoken by an external person or entity, how is it that they were able to "see" them? To the best of my knowledge, Rambachan, in his four decades of re-stating his position on the dichotomy between Vedanta and direct experience, has never dealt with this key question. What I am doing here, in effect, is sending the problem back to him and asking him for a solution in his own framework.

It is important to note that Hinduism does not regard the rishis as inherently different in substance or essence from the rest of us. Therefore, if the rishis had the capability of "seeing" the shruti without any external God speaking to them, and without any previous textual tradition or "revelation" to draw on, why can't we do so as well? If Rambachan were to respond to this question by saying we are inherently incapable of "seeing" as the rishis did, then he would be setting himself up for a massive contradiction, with core tenets of the atman being the same in everyone, rishi or not.

I am unaware of any way out of this problem other than my concluding that each human also has the same potential as the rishis, and that this potential is realized through disciplined sadhana (the inner sciences of adhyatma vidya), even though very few of us are able to realize the ultimate result in one human lifetime; most of us will need to be reborn many times in order to evolve to the rishi state.

\section{Summarizing my position on meditation}

- Since the Vedas were "seen" by the rishis, and we humans have this same capacity, each of us has the potential to achieve the same experience on his own. In other words, we, too, can know Brahman. This knowledge is not achieved by means of dualistic cognition but by non-dual cognition, which Western science is only beginning to examine.

- This study of non-dual cognition is "scientific" in that it relies on first-person empiricism which may be replicated, and because the results of that experience are examined and correlated by a community of interpreters who are free from historycentric constraints.

- This brings us head-on to Rambachan's problem, namely, that shankara did not accept any method of knowing Brahman other than the Vedas. But Shankara did develop his own meditation system (called "Nidhidhyasana") that uses specific Upanishadic mantras as the means to attain moksha. Unfortunately Shankara does not 
explain his method in much detail, though his own practice and development of the system do indicate he was not dismissive of direct experience. (Some scholars have argued that his emphasis was on refuting the opponents of his time and that this did not require that he explain his method of meditation.)

- In my book, I do not recommend any specific method of meditation. I merely assert that various methods are available to every human. My only purpose is to contrast the meditative approach with the Abrahamic notion of history-centrism and in so doing, demonstrate that we can achieve what the rishis achieved. The Jew or Christian or Muslim cannot participate in prophecy (i.e., directly receive and then declare the word of God), whereas in dharma all humans are capable of selfenlightenment without having to depend on any such historical event.

- I refer to the methods of achieving higher states of consciousness as a "science," but not in the limited sense that the term has been used in the past. Science has taken on a new meaning; it no longer denotes dualistic reductionism, something that bothers Rambachan as much as it bothers me.

None of Rambachan's arguments has any bearing on my book's central point, which is that dharmic systems are not history-centric whereas Abrahamic religions are. He simply dodges the issue of history-centrism and thus misunderstands many of my related points.

\section{Locating Integral Unity in the New Discourse}

Rambachan has devoted his distinguished career to the study of Advaita Vedanta and so it is natural that he would want this philosophy to be the central point of any discussion he enters. But my notion of integral unity cannot be collapsed into and limited to Advaita Vedanta per se, and I certainly do not consider ultimate reality to be a homogeneous, otherworldly realm, as is sometimes claimed. My interest in integrality originated as part of my study of the science of consciousness mentioned above.

Again, fundamentally, our greatest disagreement has to do with the different ways we locate our analyses. I am primarily interested in the Western appropriation of Eastern ideas, not in defending a "pure" version of Hinduism. My project is located in the history of ideas, with emphasis on the transmission of ideas from India to the West. For example, I have tracked Ken Wilber's appropriation of Sri Aurobindo's theory of integral unity, as well as Kashmir Shaivism, Tantra and Madhyamika Buddhism. I want to discuss Wilber in some depth, not only because his work and influence are much greater than most scholars of religion realize but because he exemplifies much in the contemporary Western digestion of Eastern thought.

Wilber's early books explicitly translated Indian ideas for the benefit of Western researchers, especially psychologists and philosophers. Initially he attacked Judaism and Christianity for the same kinds of problems I have cited in my book: dependence on historical and exclusive revelation, dualism, and so on. In effect, he used Indian ideas to attack Western religion and psychology and 
thus became established as a Western pioneer in what were considered "new" discoveries.

But gradually his ambition grew. Not only did he appropriate Indian ideas using his own terminology; he also claimed to have surpassed them. He said he found serious flaws in the Indian sources and that these discoveries made him reject Hinduism and promote his own formulations. His chief criticism addresses only Advaita Vedanta, which he uses to dismiss all of Hinduism. He cites only secondary interpretations of Advaita Vedanta, which he uses to claim that it is otherworldly escapism and hence incapable of achieving progress or promoting social ethics in this world. In this, he parrots the old interpretations of Christian missionaries. (These are the same views that were unfortunately adopted by Ram Mohan Roy and other Indians in the modern period as a sort of standard critique of Hinduism.)

Wilbur's appropriations and redefinitions are disingenuous given that most of his sources (again, Sri Aurobindo, Kashmir Shaivism, Tantra and Madhyamika Buddhism) do not at all espouse a homogeneous and otherworldly reality, as he is well aware. He cleverly borrows from many Indian sources, which we will call "X", and uses this to criticize one specific Indian school (Advaita Vedanta). He uses this criticism as the basis for rejecting all Hinduism. Even if his arguments about Advaita Vedanta were valid, his rejection of that school could not apply to all of Hinduism.

Wilber and his followers formulated a theory that contains no references to dharma sources; instead it refers to what are called "Integral Christianity" and "Integral Judaism." Ironically there is no Integral Hinduism in his schema, despite my having suggested to his acolytes that this ought to have been first and foremost given that the theory is based on principles that exist in Hinduism.

Wilber's reformulated dharmic ideas appeal to those Westerners who want to "come home," as it were, from their journeys into Hinduism or Buddhism, and this appeal accounts for his success in raising funds. In the process, he has rekindled Western chauvinism, using so-called universal terms in a totalizing, Hegelian fashion.

Despite Wilber's prominence and influence, no scholar of Indian religions has bothered to respond to what he is saying. Whenever I raise concerns about his misappropriations and misinterpretations among scholars of Hinduism and Buddhism, they show no interest and even dismiss his ideas as irrelevant and nonsensical. But he is relevant, and his repackaging of dharmic thought has profound implications for how Hinduism is received and understood.

An important objective of Being Different is to re-establish the dharmic foundations of what has become a large "Integral Studies" movement led by Wilber, and this requires that we redress the misinterpretation of sources (and concomitant reductionism) in his formulation. I wish to remind Wilber's camp of his own earlier assertions that Western religions are in conflict with the new ideas he has "discovered" - assertions that suggest that these religions need to be revised or reinvented in light of integral theories. What we have, then, is a massive importation of Indian ideas that are used in the transformation of Judaism and Christianity but no acknowledgment of the original sources of those ideas.

My own view of the integral unity of dharmic traditions is based on their shared methodology in terms of adhyatma vidya. This position enables me to defend these traditions 
against piecemeal appropriations such as Wilbur's and point out the shortfalls of those appropriations. Ironically Rambachan opposes my view of the integral unity of dharma, partly, I think, because he is unaware of the way in which the term "dharma" is already in play both among intellectuals and in popular discourse as well. Rambachan inadvertently provides a great service to Wilber's movement by denying that Hinduism has the metaphysics of integral unity. While Wilber appropriates his key ideas from Hinduism, Rambachan argues that such ideas are not part of Hinduism and seems unaware of the broad discourse at work. It is a triumph for Wilber to have co-opted such a major figure in Hinduism studies.

\section{Reclaiming Integral Unity as a principle of dharma}

My concept of integral unity is not to be conflated with a strict view of Advaita Vedanta as the linchpin of that unity. In fact, Appendix A of my book explains integral unity with respect to several different dharmic traditions. Hinduism's integral unity is mainly illustrated by Sri Jiva Goswami's Achintya-Bhedabheda, which is similar to Ramanuja's Vishishtadvaita. The appendix also explains integral unity from the perspective of Buddhism and Jainism.

One disagreement I have with Rambachan concerns the status of the relative and absolute worlds, or of the distinct "parts" of reality we perceive as differentiated, and the putative "whole," which is not. The diagram in Figure 2 summarizes this idea. The left and right extremes show the two common views most people have concerning the nature of a "part" of the whole reality. ${ }^{2}$ A part of the totality can be a physical object, an idea, an emotion, etc. anything we can perceive as an entity. The question then arises: What is the status of such an entity in relation to the whole? The stated assertion on the left portion of the diagram is that the entity exists by itself, i.e., that it has

self-existence. This seems intuitively obvious to the ordinary mind. After all, the tree, the table, keyboard, I, and everything I experience seem to exist. This view is dualistic. It stems from the ordinary ego state of objective cognition whereas the dharmic approach has to do with transcending that level of experience or consciousness.

The assertion on the right side represents the other extreme, which is that the entity does not exist at all, i.e., its existence is an illusion. As discussed above, this latter view has been advanced as a common interpretation of Advaita Vedanta, and it is one with which I strongly disagree.

I espouse the view in the middle, which is that the entity is mithya, a Sanskrit word with no exact equivalent in English.

\section{Object exists independently \\ Object is mithya}

Figure 2

\section{Object is \\ an illusion}


Unfortunately mithya has been seriously mistranslated as "illusion." As many commentators and acharyas in the tradition have stressed, this is incorrect. According to this middle view, every entity exists relative to something other than itself. Jiva Goswami's interpretation is that an entity exists only as a mode or form of Bhagvan and does not exist independently as itself. In other words, since Bhagvan is real, his forms are also real, but they do not have independent self-existence. (Analogy: A smile exists as a form or mode of the face, and cannot exist independently of the face.) I explain In Being Different how mithya as relative existence fits in with Buddhism's idea of mutual co-existence, though this is different from the relative existence in Hinduism because there is nothing equivalent to Brahman as an absolute. Integral unity, understood this way, is not homogeneous but has parts that are mithya. Nor is integral unity in one dharmic system the same as in another.

Rambachan accuses me of the view depicted in the diagram's right extreme, namely, that I see reality as one homogeneous whole. In doing so, he does an injustice to the concept of integral unity as I have articulated it, and responds instead with his stock position concerning Advaita Vedanta.

\section{Mantra, language and non-translatability}

A lesser but still important point Rambachan raises has to do with my emphasis on the non-translatability of Sanskrit, especially in relation to mantra. I wish to respond by drawing on a perspective from Kashmir Shaivism. Kashmir Shaivism holds that vac (speech) exists at four levels of subtlety. From most subtle to most gross, these are: para, pasyanti, madhyam and vaikhari. The first two are pre-conceptual and non-linguistic levels of vibration, and hence cannot be replaced by conventional language at all. But Sanskrit has a unique claim in that its beej mantras, or the primordial sounds that comprise its building blocks, operate at all four levels. At the lower two levels, madhyam and vaikhari, the mantras manifest as the Sanskrit primordial sounds which we speak and hear. But these levels are directly linked to the higher ones, para and pasyanti. Sanskrit is non-translatable in two respects: first, according to the dharmic view, this link is not found in any other language. There is thus a unique and irreducible nontranslatability here. Second, any language is a web of contextual relations that cannot be mapped onto a different network of contexts. Different contexts carry different meanings. Although this problem is not particular to Sanskrit, translation problems here are especially acute because the original social and cultural context is largely lost.

The non-translatability principle does not mean I do not want any Sanskrit word ever to be translated or that the work of translators is unimportant. It simply means that there should be a preference for bringing the important terms of Sanskrit into other languages as intact as possible (including sharp attention to pronunciation and intonation, which are being quickly eroded through the popularity of yoga and Westernized kirtan today) and that when translation is necessary, it should be done with the appropriate contexts and alternatives indicated. This is especially important when it comes to practice. Efforts to find discursive equivalents to mantra - as when, in meditation, "shantih" is replaced by "peace" -- entirely miss the point. 
40 Rajiv Malhotra

\section{Response to Pennington}

Much of Pennington's critique has nothing to do with my book, but is about me personally. This special issue of the Journal of HinduChristian Studies was designed as a discussion and critique of my book, Being Different, but a good deal of what Pennington writes amounts to personal attacks on me. In fact, Pennington states explicitly that he is left wondering what my motive/agenda is; he is troubled that the academy treats me as a serious scholar worthy of a seat at the table. I have decided not to respond to him by going "tit for tat" on personal matters or with insinuations.

\section{History Centrism Ignored}

Brian Pennington would seem not to understand my main points in Being Different, in particular my analysis of history-centrism as it contrasts with the relative freedom from history found in the dharmic traditions. He charges that I am mounting "an uncritical promotion of a homogenized Indic heritage whose superior character... rests on the fact that it is protected from the forces of history." Apparently he is unaware of the distinction between smirti and shruti, even though my book goes to considerable pains to highlight this distinction. Smirti is clearly historical; shruti is not. Smriti, by definition, is a product of the forces of history and is shaped by the psychology, social position, and general cultural context of humans involved in its development and transmission. Throughout his argument, Pennington suggests I am somehow "against" history and historical readings of past texts. This would be tantamount to my being against smriti, which is simply untrue.

Pennington entirely misreads my concept of history-centrism, which I have explained with some precision. History-centrism is not the same as historical consciousness or interest in historical truth, both of which are definitely present in Indian thought. Rather, it is about a certain reification of the historical record of God's interventions through prophets. These (alleged) recorded occurrences are then used as the basis for theological claims, political projects, and religious practices.

The point of difference, again, concerns shruti, not smriti: The direct experience of shruti is possible for all humans whereas in the Abrahamic religions, prophecy is not available to all humans, in part because the time and place matter and sometimes even determine the content of the revelation. Let me repeat: in the dharmic view, shruti is independent of history, but smriti is not. The Hindu texts are careful to keep these separate and the traditions have generally drawn a clear and logical boundary between them. In the JudeoChristian religions, the two categories are collapsed. Both the Hebrew Bible and the New Testament have content for which shruti status may be claimed as well as other content that can only be explained as smriti. (In fact, the Bible is full of material that, from a dharmic point of view, would be called purana or itihas.) The primary task of Christian and Jewish exegesis is to draw and redraw the line between these two aspects. There are extreme positions at both ends. Fundamentalists argue that the whole of their Bible is revelation, what the dharmic view would label as shruti; liberal revisionists and secularists argue that all or most of it is historical tradition, i.e., what the dharmic would classify as smirti. The whole process in the west is, however, clouded and sometimes even violent, once again because of the problem of history centrism. The particular 
manifestation of God in specific and unrepeatable events in time and through specially honored persons or prophets implies that the very content of these revelations is historical and the historical identity, authority and destiny of the messengers affects, and to some degree determines, the message (which does not have the same weight if uttered by anyone other than a prophet). Historycentrism also puts witnesses in conflict with one another since there cannot be a plurality of views on the actuality of a historical event. Hence the two categories of history and eternal truth become cloudy at every turn. The dharmic traditions do not have this problem, not because they are a-historical but because they distinguish clearly between the two categories.

None of the three scholars really engages with history centrism, which is a central concept in my work. In part, this is because they do not look at the Judeo-Christian tradition through dharmic lenses. Their view of Western religions is conditioned (no doubt unconsciously) by their Western training and assumptions. Westerners often find it troubling to deal with their history centrism as seen from a dharmic viewpoint.

\section{Creating a Binary: Hindu Fundamentalism or non-existent Hinduism}

Pennington further implies that in defending the "difference" intrinsic in dharma I am in some way colluding with the rise of Hindu fundamentalism and with its attempted suppression of minorities. Unfortunately, today it is virtually impossible to make any positive assertions about Hinduism without incurring this kind of slur. It is as if arguing for a distinct
Hindu dharma were the same as arguing for the homogenization of India and thus for fascism. This prejudiced reading of my work creates a smoke screen for failure or refusal to engage with my particular assertions about Hinduism. So let me say once again that I fully support the pluralistic construction of political and social structures that will protect and advance the rights of all peoples and especially minorities, women and the poor.

There is a silent assumption that the only way to avoid Hindu fundamentalism is to adopt the position that there is no such thing as a unified Hindu dharma. I have already spoken of a version of this view which I think Rambachan holds, albeit tacitly. Pennington has to confront this view more directly as he faces high stakes in this debate. He is best known for having written the book Was Hinduism Invented?, which argues that Hinduism was fabricated under British influence and that this fabrication accounts for its alleged lack of coherence, unity and continuity, i.e., it is a sort of fraud.

I argue the contrary. Not only is there such a thing as Hinduism; it has a long history and has a vital role to play in the public sphere. The alternative of a repressive secularism -- which many scholars, either explicitly or implicitly, would seem to support -- is a disaster in the making. I wish to see the dharmic principles adapted for a contemporary pluralistic society. In my book I expressly advocate mutual respect for other faiths; hence arguing in favor of the integral unity of dharmic traditions does not, in any way, subordinate other traditions. By the same token, this mutual respect does not mean that the voice of Hinduism should be silenced -an outcome to which Pennington's position would surely lead. 
Pennington argues, in a related vein, that it is my intention "to studiously avoid any suggestion that dharmic traditions are multiple, distinct in their various expressions, or products of disparate influences." He quotes me - quite accurately -- as saying that "if dharma is put forward merely as an eclectic collection of disparate ideas, it will lack the cohesiveness necessary to function as a force for change." But these two statements, his and mine, do not correspond in any way. of course, dharmic traditions are multiple and distinct; that is precisely the thing about them that I wish to uphold. And of course they are the product of various influences: historical, social, intellectual, cultural and experiential. I have often said as much. I do not, however, hold that they lack internal coherence.

\section{Differences in 'Chaos' Narratives}

Pennington goes on to question my "categorical" assessment that Westerners are especially uneasy about the notion of variation and nuance in the domain of ethics, that they see India and Indians as lacking in ethical principles, and that for similar reasons they are baffled and disturbed by Indian aesthetics. But my position here is based squarely on a great deal of evidence in a large number of sociological and psychological studies, evidence which I present and annotate copiously in Being Different.

My book adds two analytic points to that body of evidence: (1) the Western response originates in a fear of chaos, and (2) this fear has deep roots in both Biblical and Hellenistic cosmology. It is in this context that I offer a comparative reading of narratives found in Genesis, Homer and Indian sources. I do indeed, as Pennington claims, treat these narratives as "unity templates for moral action and the apprehension of reality," but I do so because this is precisely how they have functioned in the religious lives of many people. To study and critique narratives in these terms is a wellestablished practice in the humanities, and to suggest that my doing so is somehow tantamount to a denial of historical context and conditioning is a serious misreading.

\section{Pennington's high stakes}

Pennington has long argued against "Hinduism" as a legitimate term, and naturally he wishes to safeguard and defend his previous work. Hence, he attacks my treatment of Hinduism as coherent and also a positive resource. Yet he has not been able to pinpoint any central or fundamental flaws in my treatment, at least not in any compelling way.

Perhaps it is for this reason that he turns from the book he was supposed to review and takes aim instead at my prior, unrelated work of many years ago. In fact he states explicitly that he accepted this invitation to write in order to address his old gripes with what he sees as my "career as a Hindu activist." $\mathrm{He}$ writes:

Why do Princeton and the University of Massachusetts offer him a podium? Why does the International Journal of Hindu Studies organize a symposium on his work? Why does the Society for Hindu-Christian Studies honor him with serious discussion of his book at one of the only two sessions it holds annually and with a symposium in the one issue of its annual journal?

Unable to refute, or even engage with, my book's arguments, he thus resorts to dismissing my right to be at the table in current debates. 


\section{Aastika: Coherence and change}

Why does Pennington wish to exclude me from the table? To answer this, we must address the difficult question of what constitutes religious studies - and indeed religion itself - in today's world. Is religion defined by one fixed and frozen canon to be interpreted only by academic scholars and "legitimate" exegetists? Or is it a living, organic entity that evolves, with new discoveries and contexts that encourage "churning" among its practitioners, often resulting in new forms of consensus that challenge and replace old ones? I claim it is the latter. Hinduism is arguably the most dynamic of the major religions, with a long history of diverse schools and a seemingly inexhaustible supply of new gurus who debate amongst themselves without a central nexus of authority to adjudicate over them. Put another way, these gurus are like intellectual entrepreneurs who compete with each other by advancing new ideas, revising old ones, etc. I have argued that Hinduism's freedom from absolutist history centrism accounts for this dynamism, which I think should be encouraged at the academic level as well.

The term "aastika" is useful in gaining an understanding of this churning practice in Hinduism's long history and in appreciating the unity in dharma. "Aasitka" encapsulates how Hindus have vigorously debated the criteria for what constitutes their faith. The very existence of such a term at the center of Hindu discourse shows that the quest for coherence is very old. At the same time, the definition of aastika has long been vigorously contested and debated. In stark contrast to the Nicene Creed of Christianity $^{3}$, there is no static, history-centric statement or institutionalized criterion for aastika. The phenomenon of multiple Hindu gurus formulating innovative interpretations that challenge established ones can be traced back to classical times. Vivekananda, Gandhi, Sri Aurobindo, Ramana Maharshi - these are but a few of the modern gurus who have reformulated Hindu dharma for their own contexts. But again, the trend is much older. There is nothing new or "manufactured" about this dynamism, in spite of what Pennington would have us believe.

So coherence and unity exist but in a dynamic equilibrium that is conducive to rigorous, constructive debate. This aspect of Hinduism poses a serious problem for Western academics, whose methods were developed for the less fluid and more reified "religions of the book." It is time for the academy to re-imagine Hindu dharma on new terms, and this requires engaging those thinkers whose voices the Hindu communities recognize as their own.

\section{Pennington's problem in locating me in his stereotypes}

With respect to my work in particular, it troubles Pennington that he cannot locate me in his limited, narrow framework of where Hindus belong. There are two main ways in which Hindus have participated in the Western academy.

One way is as an outsider, or "native informant," who has less power in relation to the scholar and who seldom talks back or shares in the prestige and recognition of authorship. He certainly does not get a chance to articulate what he sees when he "reverses the gaze," i.e., ceases to be the object and fixes his own gaze on the Westerner. It is mostly poor villagers who have been "studied" as native informants, though many gurus have been as well, and often with their full co- 
operation. These gurus are largely ignorant of the "playing field" and in many cases are dependent on Western patronage.

The second way a Hindu participates in Western studies is as a scholar inside the academy, where he is under great pressure to adopt the syndicated and authorized hermeneutics of his mentors and peers, and often compromises his own tradition's siddhanta (theory and method) in doing so. Many such individuals have told me they, in effect, lead double lives: privately they can agree with me and even help me in my own pursuit of reform, but in front of peers, they must protect their careers by closing ranks. Some Hindu scholars have gone even further and marketed themselves as "sepoys," to be used as "hit men" against uncontrollable Hindus like me who refuse to submit.

Pennington's problem is that I fit into neither category. I am not a benign, passive native informant available to help scholars by supplying them with the data that they want to hear. Nor do I tailor my scholarship to fit current academic norms in the study of Hinduism.

Pennington also takes umbrage at my pointed attacks on the self-validating and closed circle of peer review in the academy and on the prevalence of heavy funding for the study of hypotheses that "just happen" to support or benefit projects of Western hegemony, both intellectual and political. I would simply like to point out that while corruptions of the peer review system in the academy become scandals in the sciences, they go largely unnoticed in the humanities, and had I taken a more deferential and subaltern tone in drawing attention to them, my argument would have gained no hearing whatsoever.

In the case of Being Different, however, Pennington is simply wrong in stating that I wrote it as a way of "speaking back to the academy." He also alleges that I wrote the book as a way of engaging directly with the scholarly world. Indeed, a decade back I did focus on changing the Western system through its own guardians, but for many years now, most of my target audience has been from the Hindu dharma community in the broad sense. In the process, I have actively engaged the leading gurus, civic and industry leaders, as well as scholars, both in India and North America. As the record shows, my book has reading lists in Indian university departments of psychology, management, social sciences, technology, etc. Also, my critique of the inauthentic appropriation of Indian ideas and practices has placed certain Western schools of thought under scrutiny. This broad reception is based on the realization that what I am proposing is "a new gaze," both internally, at Hinduism itself, and externally, at the West -- a gaze moreover which empowers Hindus to see themselves as global citizens with dharmabased identities. Thanks to the power of the internet and social media in general, my book is having a global impact. It is also now reaching American classrooms, where people like Pennington teach.

As a result not just of my work in this area but also of a much broader movement of ideas, the Western academy no longer enjoys a monopoly on shaping the public's understanding of "the East." Americans today receive their ideas about Indian traditions through travel, the workplace, Indian friends, 
novels, art, popular culture, the Internet, and other emerging channels.

This increasingly well-informed readership regards many of the old-school portrayals of Hinduism as bizarre, inaccurate and unreliable. My own work provides a much-needed analytic platform for their concerns, as even those within the academy are starting to realize. When I do address the academy (and I do so only by invitation), I try to hold its leading scholars accountable for the misinformation and confusion they spread, and to expose how these errors arise from self-perpetuating structures and entrenched positions. If this in itself makes me appear as a threat, I feel satisfied that my work is making a difference. I am glad there are a growing number of serious and open-minded academicians who wish to engage with the substance of my arguments while taking the wider context into account.

\section{Response to Edelman}

Like Rambachan and Pennington, Jonathan Edelman expresses concern about my treatment of science and history-centrism, and takes me to task for not understanding the diversity of both Hinduism and Christianity. He asserts that I oversimplify the tension between religion and science in the West, and cites the (very infrequent) acceptance of scientific views by Christians and the new blurring of the boundaries between science and religion as exemplified by the John Templeton Foundation.

First, it is a matter of historical record that Christianity and science in the West have long been violently opposed. Galileo was censured by the church and Darwin's theories were strongly resisted in most mainstream Christian circles. This resistance lives on in political and legal disputes over the teaching of evolution in American schools today. Second, I am well aware of the blurring of the line between science and religion today, though I do not think it takes quite the simplistic form Edelman suggests. I have explained my views on this in detail in my response, above, to Rambachan. A third point: the Templeton Foundation's program on science and religion was largely built by scholars who borrowed Hindu and Buddhist ideas; most of its initial thinkers drank heavily from those wells. Figure 1 lists Templeton as one of the major organizations built on digesting dharmic knowledge and transforming it into new frameworks that appear to be original.

With respect to the question of historycentrism, Edelman notes that certain Hindu traditions give central theological authority to a particular purana and make its author central as well. But here again, he misses the point. It is not that Indian thought does not take note of the particular circumstances of certain texts or value their association with certain authors. of course these texts and authors arrive in time; how else could they occur? of course the teachings about Brahman have a history and a context and even, at points, an internal unfolding order. But these teachings do not depend on specific historical events and validations equivalent to the exodus of the Israelites from Egypt under Moses or the resurrection of Jesus. In Judaism and in Christianity, respectively, they do. The distinctions between shruti and smriti help to illuminate this point.

The important question here is: Would the theology of bhakti be significantly different if it were "proved" that the Bhagavata Purana came to someone other than Vyasa, or at some other 
time or place? The answer is: not at all. But if it were proved that the Ten Commandments were delivered outside of the Jewish tradition and Jewish history, or if they were, say, delivered out of sequence with regard to other key revelations in Judaism, then that religion would be profoundly affected. Jews could no longer see themselves as unique bearers of truth in history with unique privileges and responsibilities. Likewise, if the revelation that God is the savior came to someone other than Jesus, Christians could no longer believe either in the incarnation or the trinity, the two essential doctrinal pillars of their faith. For Vaishavites, however, the bhakti reinterpretation of the whole of the Vedic past is true, and would be true even if someone else in some other time and place had discovered it. Its validity does not depend on historical events contemporary with the discovery or on the particular ethnic and historical identity of Vyasa himself. Vaishnavites do not claim that this history created a new, unique covenant or new ritam that was previously unavailable and that is available today only through the knowledge of that covenant and no other way.

The importance of history to salvation in the West is well-recognized and if that were all I were saying, I would indeed be uttering a commonplace, as Edelman claims. But that is not all. I am speaking of a primacy given to historical events themselves that goes beyond the role of history in other major religious or philosophical traditions and that seriously blocks any genuine pluralism. For Hindus and Buddhists this point is often difficult to grasp. The complex relationship between the line of prophets in the Abrahamic religions -- that is, between Abraham, Moses, Jesus and Mohammed, to name only the key ones -- does not at all operate like a parampara or line of transmission in dharma, even though Edelman claims it does. Among other things, these prophets are in competition with one another for complete and exclusive control over their respective traditions, and that control depends, as I have said, on their place in an unfolding linear temporality and on the events and outcomes of history itself.

Edelman also criticizes what he takes to be my lack of awareness of the diversity within Christianity. In my view (that is, the dharmic view), this notion of Christian diversity is myopic at best. Clearly people like Edelman feel the need to rescue the West from its history of violent suppression of diverse religious views, and so they repeatedly hold up the example of a few dissenters. (These are mostly American Protestants of the past two centuries who no longer represent the Christian mainstream, if in fact they ever did.) Edelman cites, for instance, Christians who do not find it necessary to believe in the historical Jesus and his resurrection or in the basic historical accuracy of the gospels' accounts of this event. That such persons exist I do not doubt; indeed I have enjoyed meting a few. But strictly speaking they are not mainstream Christians and cannot, in good conscience, sign on to any of the basic creeds and affirmations by which Christianity, in any recognized denomination, is defined. An affirmation of precisely this set of beliefs is, as I point out in Being Different, built into the creed that is the gold standard of Christian orthodoxy and that is said every Sunday in every church with a legitimate claim to Christian identity. Belief in the historical accuracy of the accounts of Jesus' rising from the dead in the gospels was re-emphasized as a key article of faith even at Vatican II, the 
Church council that supposedly liberalized so many other Roman Catholic doctrines.

On the matter of Hindu education, the importance of the study of Sanskrit, and the full recognition and support of both Western and Indian scholars who attempt to save and preserve the textual tradition, I am entirely in agreement with Edelman, as the record of projects I have funded through the Infinity Foundation clearly shows.

\section{Notes}

${ }^{1}$ See Being Different, pp. 124-126.

${ }^{2}$ A similar point can be made using particulars and universals instead of parts and wholes. ${ }^{3}$ The criteria for being aastika have varied over time. These include: one who "affirms the value of ritual" (Medhatithi); one who "affirms the existence of virtue and vice" (Hariibhadra); one who "affirms the existence of another world after death" (the grammarians); and one who "affirms the Vedas as the source of ultimate truth" (Vijnanabhiksu Madhava, etc.). 